\title{
Front Matter: Volume 8786
}

, "Front Matter: Volume 8786," Proc. SPIE 8786, Pacific Rim Laser Damage 2013: Optical Materials for High Power Lasers, 878601 (24 July 2013); doi: 10.1117/12.2030524

SPIE Event: SPIE/SIOM Pacific Rim Laser Damage: Optical Materials for HighPower Lasers, 2013, Shanghai, China 


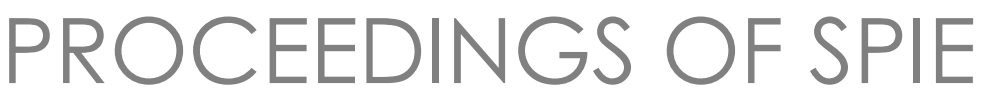

\title{
Pacific Rim Laser Damage 2013 Optical Materials for High Power Lasers
}

\author{
Jianda Shao \\ Takahisa Jitsuno \\ Wolfgang Rudolph \\ Editors
}

19-22 May 2013

Shanghai, China

Sponsored by

SPIE

SIOM-Shanghai Institute of Optics and Fine Mechanics

Cosponsored by

SCHOTT

OptoTech Germany

PulsePower

Cooperating Organizations

Chinese Optical Society

Chinese Academy of Sciences

Published by

SPIE 
The papers included in this volume were part of the technical conference cited on the cover and title page. Papers were selected and subject to review by the editors and conference program committee. Some conference presentations may not be available for publication. The papers published in these proceedings reflect the work and thoughts of the authors and are published herein as submitted. The publisher is not responsible for the validity of the information or for any outcomes resulting from reliance thereon.

Please use the following format to cite material from this book:

Author(s), "Title of Paper," in Pacific Rim Laser Damage 2013: Optical Materials for High Power Lasers, edited by Jianda Shao, Takahisa Jitsuno, Wolfgang Rudolph, Proceedings of SPIE Vol. 8786 (SPIE, Bellingham, WA, 2013) Article CID Number.

ISSN: 0277-786X

ISBN: 9780819496027

Published by

SPIE

P.O. Box 10, Bellingham, Washington 98227-0010 USA

Telephone +1 3606763290 (Pacific Time) · Fax +1 3606471445

SPIE.org

Copyright (C) 2013, Society of Photo-Optical Instrumentation Engineers.

Copying of material in this book for internal or personal use, or for the internal or personal use of specific clients, beyond the fair use provisions granted by the U.S. Copyright Law is authorized by SPIE subject to payment of copying fees. The Transactional Reporting Service base fee for this volume is $\$ 18.00$ per article (or portion thereof), which should be paid directly to the Copyright Clearance Center (CCC), 222 Rosewood Drive, Danvers, MA 01923. Payment may also be made electronically through CCC Online at copyright.com. Other copying for republication, resale, advertising or promotion, or any form of systematic or multiple reproduction of any material in this book is prohibited except with permission in writing from the publisher. The CCC fee code is 0277-786X/13/\$18.00.

Printed in the United States of America.

Publication of record for individual papers is online in the SPIE Digital Library.

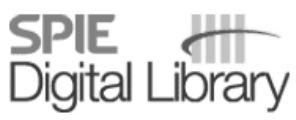

SPIEDigitallibrary.org

Paper Numbering: Proceedings of SPIE follow an e-First publication model, with papers published first online and then in print and on CD-ROM. Papers are published as they are submitted and meet publication criteria. A unique, consistent, permanent citation identifier (CID) number is assigned to each article at the time of the first publication. Utilization of CIDs allows articles to be fully citable as soon as they are published online, and connects the same identifier to all online, print, and electronic versions of the publication. SPIE uses a six-digit CID article numbering system in which:

- The first four digits correspond to the SPIE volume number.

- The last two digits indicate publication order within the volume using a Base 36 numbering

system employing both numerals and letters. These two-number sets start with 00, 01, 02, 03, 04, $05,06,07,08,09,0 A, 0 B \ldots 0 Z$, followed by 10-1Z, 20-2Z, etc.

The CID Number appears on each page of the manuscript. The complete citation is used on the first page, and an abbreviated version on subsequent pages. Numbers in the index correspond to the last two digits of the six-digit CID Number. 


\section{Contents}

ix Conference Committee

HIGH POWER LASER DAMAGE, UV THROUGH IR I

878602 Femtosecond to nanosecond laser damage in dielectric materials (Plenary Paper) [8786-1] W. Rudolph, L. A. Emmert, C. Rodriguez, Z. Sun, X. Zhang, Y. Xu, The Univ. of New Mexico (United States); C. S. Menoni, P. F. Langston, E. Krous, D. Patel, Colorado State Univ. (United States)

878603 Optical damage limits in chalcogenide nonlinear crystals used in $1064 \mathrm{~nm}$ pumped nanosecond optical parametric oscillators (Invited Paper) [8786-2]

V. Petrov, G. Marchev, A. Tyazhev, M. Starikova, Max-Born-Institute for Nonlinear Optics and Ultrafast Spectroscopy (Germany); A. Esteban-Martin, Max-Born-Institute for Nonlinear Optics and Ultrafast Spectroscopy (Germany) and ICFO-Institut de Ciencies Fotoniques (Spain); V. Panyutin, Max-Born-Institute for Nonlinear Optics and Ultrafast Spectroscopy (Germany); V. Badikov, G. Shevyrdyaeva, D. Badikov, Kuban State Univ. (Russian Federation); M. Reza, Max-Born-Institute for Nonlinear Optics and Ultrafast Spectroscopy (Germany); S. Sheina, A. Fintisova, Kuban State Univ. (Russian Federation)

878604 Comparison of fused silica and oxyfluoride glass on laser induced initial damage morphology [8786-3]

Q. Cheng, Nanjing Univ. of Posts and Telecommunications (China) and China Academy of Engineering Physics (China); J. Huang, X. Zhou, L. Sun, X. Jiang, Z. Sui, China Academy of Engineering Physics (China); C. Hou, Xi'an Institute of Optics and Precision Mechanics (China); W. Wei, B. Peng, Nanjing Univ. of Posts and Telecommunications (China) and Xi'an Institute of Optics and Precision Mechanics (China)

\section{LASER ABLATION AND LASER MACHINING I}

878607 Laser damage and ablation with femtosecond pulses: recent measurements and applications (Invited Paper) [8786-5]

O. Utéza, R. Clady, M. Lebugle, N. Sanner, M. Sentis, Aix-Marseille-Univ., CNRS (France); Y. Li, Y. Shen, Northwest Institute of Nuclear Technology (China)

878608 Nd:YAG laser conditioning of KDP crystals investigated using nondestructive optical diagnostics [8786-68]

D. Guo, Univ. of Electronic Science and Technology of China (China) and China Academy of Engineering Physics (China); X. Jiang, J. Huang, F. Wang, H. Liu, China Academy of Engineering Physics (China); Y. Jiang, Univ. of Electronic Science and Technology of China (China) and China Academy of Engineering Physics (China); X. Xiang, X. Zu, Univ. of Electronic Science and Technology of China (China) 
8786 OA Design and development of an automated laser processing system for photovoltaic applications [8786-10]

J. Chen, Z. Wu, ZC Optoelectronic Technologies, Ltd. (China)

LASER ABLATION AND LASER MACHINING II

8786 OB Recent progresses on insights of laser damage mechanisms and influence of contamination in optics (Plenary Paper) [8786-33]

T. Jitsuno, Osaka Univ. (Japan); H. Murakami, Osaka Univ. (Japan) and Promotion Ctr. for Laser Technology (Japan); K. Kato, Promotion Ctr. for Laser Technology (Japan) and Institute for Laser Technology (Japan); E. Sato, K. Mikami, Osaka Univ. (Japan);

S. Motokoshi, Institute for Laser Technology (Japan); N. Miyanaga, H. Azechi, Osaka Univ. (Japan)

8786 OC Laser-induced damage in porous glass: a pathway to 3D fabrication of micro-/nanofluidics (Invited Paper) [8786-11]

Y. Cheng, Y. Liao, Shanghai Institute of Optics and Fine Mechanics (China); K. Sugioka, RIKEN (Japan)

8786 OD Volumetric modifications in fused silica using Gaussian and Bessel femtosecond laser beams [8786-13]

D. Paipulas, Vilnius Univ. (Lithuania); M. Mikutis, Vilnius Univ. (Lithuania) and Altechna RD (Lithuania); V. Sirutkaitis, Vilnius Univ. (Lithuania); S. Juodkazis, Swinburne Univ. of Technology (Australia)

8786 OE Laser cutting of ultra-thin glasses based on a nonlinear laser interaction effect [8786-14] J. Chen, Z. Wu, ZC Optoelectronic Technologies, Ltd. (China)

\section{LASER CERAMICS}

$8786 \mathrm{OL} \quad$ Hot-pressed Cr:ZnSe ceramic as mid-infrared laser material [8786-22]

M. Chen, W. Li, H. Kou, B. Jiang, Y. Pan, Shanghai Institute of Ceramics (China)

DEFECTS, CONTAMINATION, POLISHING, AND SURFACE DAMAGE

878600 Effect of pulse energy and numbers on fused silica surface by ultraviolet laser pulses at $355 \mathrm{~nm}$ in vacuum [8786-25]

X. Zhou, X. Zhou, J. Huang, Q. Cheng, F. Wang, X. Ye, X. Jiang, W. Wu, China Academy of Engineering Physics (China)

8786 OP The effect of RIE-modified surface contamination on optical performance of fused silica [8786-26]

L. Sun, H. Liu, J. Huang, X. Ye, Q. Cheng, X. Zhou, F. Wang, X. Jiang, W. Wu, China Academy of Engineering Physics (China)

$8786 \mathrm{OQ}$ Improve the laser damage resistance of fused silica by wet surface cleaning and optimized HF etch process [8786-27]

X. Jiang, Y. Liu, H. Rao, S. Fu, Univ. of Science and Technology of China (China) 
8786 OR A new polishing process for large-aperture and high-precision aspheric surface [8786-28] X. Nie, S. Li, Y. Dai, C. Song, National Univ. of Defense Technology (China)

8786 OS Using light scattering to investigate damage-relevant imperfections of surfaces, coatings, and bulk materials [8786-29]

S. Schröder, M. Trost, T. Herffurth, A. Duparré, Fraunhofer Institute for Applied Optics and

Precision Engineering (Germany)

NONLINEAR LASER CRYSTALS I

8786 OU Transverse stimulated Raman scattering gain coefficient measurement in KDP crystal [8786-31]

Y. Guo, S. Tang, H. Hui, Y. Wang, Q. Tang, B. Zhu, Z. Lin, Shanghai Institute of Optics and Fine Mechanics (China)

8786 OV Diode pumped neodymium doped ASL ( $\left.\mathbf{S r}_{1-x} \mathbf{L a}_{x-y} \mathrm{Nd}_{y} \mathbf{M g}_{x} \mathrm{Al}_{12-\mathrm{x}} \mathrm{O}_{19}\right)$ laser [8786-32]

L. Zheng, Lab. de Chimie de la Matière Condensée de Paris (France) and Shanghai Institute of Ceramics (China); P. Loiseau, G. Aka, Lab. de Chimie de la Matière Condensée de Paris (France)

\section{HIGH LASER DAMAGE RESISTANT COATINGS}

8786 0X Research on the laser damage performance of high reflection coatings at $355 \mathrm{~nm}$ (Invited Paper) [8786-34]

M. Zhu, J. Shao, K. Yi, Shanghai Institute of Optics and Fine Mechanics (China); X. Li, Z. Yu, Shanghai Institute of Optics and Fine Mechanics (China) and Univ. of Chinese Academy of Sciences (China); W. Zhang, H. Qi, Shanghai Institute of Optics and Fine Mechanics (China)

$8786 \mathrm{OZ}$ Effect of laser conditioning on the LIDT of $532 \mathrm{~nm} \mathrm{HfO}_{2} / \mathrm{SiO}_{2}$ reflectors [8786-36]

J. Liu, X. Li, Z. YU, H. Cui, Shanghai Institute of Optics and Fine Mechanics (China) and Univ. of Chinese Academy of Sciences (China); W. Zhang, M. Zhu, K. Yi, Shanghai Institute of Optics and Fine Mechanics (China)

878610 Optimization of the optical near-field distribution of metal multilayer dielectric gratings for pulse compressors [8786-37]

H. Guan, Shanghai Institute of Optics and Fine Mechanics (China) and Univ. Of Chinese Academy of Sciences (China); Y. Jin, S. Liu, F. Kong, Y. Du, K. He, M. Fang, K. Yi, J. Shao, Shanghai Institute of Optics and Fine Mechanics (China)

\section{NONLINEAR LASER CRYSTALS II}

878614 Fluoride crystals: materials for near-infrared solid state lasers (Invited Paper) [8786-41] D. Parisi, S. Veronesi, NEST Istituto Nanoscienze, CNR (Italy) and Univ. di Pisa (Italy); A. Volpi, Univ. di Pisa (Italy); M. Gemmi, NEST Istituto Italiano di Nanotecnologia (Italy); M. Tonelli, NEST Istituto Nanoscienze, CNR (Italy) and Univ. di Pisa (Italy); A. Cassanho, H. P. Jenssen, AC Materials, Inc. (United States) 
878616 Passively Q-switched Tm:BaY $2 F_{8}$ lasers [8786-43]

H. Yu, Max-Born-Institute for Nonlinear Optics and Ultrafast Spectroscopy (Germany) and Shandong Univ. (China); S. Veronesi, NEST Istituto Nanoscienze, CNR (Italy) and Univ. di Pisa (China); X. Mateos, Univ. Rovira i Virgili (Spain); V. Petrov, U. Griebner, Max-Born-Institute for Nonlinear Optics and Ultrafast Spectroscopy (Germany); D. Parisi, M. Tonelli, NEST Istituto Nanoscienze, CNR (Italy) and Univ. di Pisa (Italy)

\section{CHARACTERIZATION TECHNIQUES AND MEASUREMENT PROTOCOLS}

878618 Influence of the test parameters on LIDT determination for single and multiple laser irradiations in optical components in nanosecond regime (Invited Paper) [8786-45] J.-Y. Natoli, F. Wagner, C. Gouldieff, M. Commandré, Aix-Marseille-Univ., CNRS, Ecole Centrale Marseille, Institut Fresnel (France)

8786 1 A Study of photothermal response in thin film coatings by ellipsometry [8786-47] J. Dong, J. Chen, Z. Wu, Hefei ZC Optoelectronic Technologies (China)

HIGH POWER LASER DAMAGE, UV THROUGH IR II

8786 IG Research and construction progress of the SG-III laser facility (Invited Paper) [8786-53] Q. Zhu, W. Zheng, X. Wei, F. Jing, D. Hu, W. Zhou, B. Feng, J. Wang, Z. Peng, L. Liu, Y. Chen, L. Ding, D. Lin, L. Guo, Z. Dang, X. Deng, China Academy of Engineering Physics (China)

HIGH POWER LASER DAMAGE, UV THROUGH IR III

878611 Fundamental mechanisms of laser-induced damage in optical materials: today's state of understanding and problems (Plenary Paper) [8786-55]

A. A. Manenkov, A.M. Prokhorov General Physics Institute (Russian Federation)

8786 1J Laser-induced damage thresholds at different temperature for optical devices (Invited Paper) [8786-56]

K. Mikami, Osaka Univ. (Japan); S. Motokoshi, T. Somekawa, Institute for Laser Technology (Japan); T. Jitsuno, Osaka Univ. (Japan); M. Fujita, Institute for Laser Technology (Japan); K. A. Tanaka, Osaka Univ. (Japan)

8786 1M Development of a "turn-key" system for weak absorption measurement and analysis [8786-58]

J. Chen, J. Dong, Z. Wu, ZC Optoelectronic Technologies, Ltd. (China)

8786 iN Laser-induced-damage threshold of periodically poled lithium niobate for $1030 \mathrm{~nm}$ femtosecond laser pulses at $100 \mathrm{kHz}$ and $75 \mathrm{MHz}$ [8786-59]

I. Pipinytè, R. Grigonis, K. Stankevičiūte, Vilnius Univ. Laser Research Ctr. (Lithuania); S. Kičas, R. Drazdys, Ctr. for Physical Sciences and Technology (Lithuania); R. C. Eckardt, Gooch \& Housego (United States); V. Sirutkaitis, Vilnius Univ. Laser Research Ctr. (Lithuania) 
878610 Ultraviolet laser-induced damage growth characteristic and mechanism on the surface of fused silica [8786-60]

Z. Fang, Shanghai Institute of Optics and Fine Mechanics (China) and Univ. Of Chinese Academy of Sciences (China); Y. Zhao, G. Hu, Shanghai Institute of Optics and Fine Mechanics (China); S. Chen, Shanghai Institute of Optics and Fine Mechanics (China) and Univ. of Chinese Academy of Sciences (China); D. Li, J. Shao, Shanghai Institute of Optics and Fine Mechanics (China)

POSTER SESSION

8786 IR A research of weak absorption measurements in crystal based on photothermal interferometry [8786-63]

B. Chen, Z. Liu, S. Wang, Crystech Inc. (China)

8786 is Annular polishing of large-aperture Nd-doped metaphosphate glasses [8786-64] $\mathrm{H}$. Shan, Shanghai Institute of Optics and Fine Mechanics (China) and Univ. of Chinese Academy of Sciences (China); X. XU, H. He, F. Wu, K. Yi, J. Shao, Shanghai Institute of Optics and Fine Mechanics (China)

$87861 \mathrm{U}$ Experimental simulation of radioactive decontamination with Excimer laser [8786-66] Z. Gao, X. Tang, M. Ma, Z. Zhang, China Institute of Atomic Energy (China)

$87861 \mathrm{~W}$ Optical properties of phase shift on reflection and/or transmission through biaxial anisotropic thin films [8786-69]

Y. Hou, Shanghai Institute of Optics and Fine Mechanics (China) and Univ. of Chinese Academy of Sciences (China); H. Qi, Shanghai Institute of Optics and Fine Mechanics (China); X. Li, K. He, Shanghai Institute of Optics and Fine Mechanics (China) and Univ. of Chinese Academy of Sciences (China); M. Fang, K. Yi, J. Shao, Shanghai Institute of Optics and Fine Mechanics (China)

$87861 \mathrm{X}$ Damage initiation and growth in multilayer dielectric films at $1064 \mathbf{n m}$ [8786-70] W. Liu, Shanghai Institute of Optics and Fine Mechanics (China) and Univ. of Chinese Academy of Sciences (China); C. Wei, D. Li, Shanghai Institute of Optics and Fine Mechanics (China); J. Sun, Shanghai Institute of Optics and Fine Mechanics (China) and Univ. of Chinese Academy of Sciences (China); K. Yi, J. Shao, Shanghai Institute of Optics and Fine Mechanics (China)

8786 IY Rheological properties of magnetorheological fluid and its finishing application on large aperture BK7 glass [8786-71]

C. Wang, Q. L. Wei, W. Huang, Q. Luo, J. G. He, G. P. Tang, Institute of Mechanical Manufacturing Technology (China)

878612 Simulation study on the influence of subsurface deficiency on fused silica laser damage threshold [8786-72]

L. Chen, Zhejiang Univ. (China) and Northwest Institute of Nuclear Technology (China);

Z. Xiang, Zhejiang Univ. (China); C. Jing, Northwest Institute of Nuclear Technology (China)

878620 Laser-induced damage resistance of AlF 3 films [8786-73]

J. Sun, X. Li, Shanghai Institute of Optics and Fine Mechanics (China) and Univ. of Chinese Academy of Sciences (China); W. Zhang, K. Yi, J. Shao, Shanghai Institute of Optics and Fine Mechanics (China) 
878621 Stress-induced waveguides written by femtosecond laser in phosphate glass [8786-74] M.-M. Dong, Univ. of Chinese Academy of Sciences (China) and Shanghai Institute of Optics and Fine Mechanics (China); Q.-Z. Zhao, Shanghai Institute of Optics and Fine Mechanics (China)

878622 Mechanism for $355 \mathrm{~nm}$ nanosecond-pulse-driven damage in $\mathrm{HfO}_{2} / \mathrm{SiO}_{2}$ high reflectivity coating [8786-75]

Z. Yu, Shanghai Institute of Optics and Fine Mechanics (China) and Univ. Of Chinese Academy of Sciences (China); H. He, H. Qi, Shanghai Institute of Optics and Fine Mechanics (China); S. Chen, Shanghai Institute of Optics and Fine Mechanics (China) and Univ. of Chinese Academy of Sciences (China); Q. Xiao, Shanghai Institute of Optics and Fine Mechanics (China)

878623 Research on microcracks avoidance in processing of $a-\mathrm{Al}_{2} \mathrm{O}_{3}$ by ultrashort laser pulses [8786-76]

C.-W. Wang, Shanghai Institute of Optics and Fine Mechanics (China) and Univ. of Chinese Academy of Sciences (China); Q.-Z. Zhao, Shanghai Institute of Optics and Fine Mechanics (China)

878626 Infrared analysis of optical fiber cladding materials during the quenching, irradiating, and annealing process [8786-80]

W. Wu, Shanghai Applied Radiation Institute (China); J. Yin, Z. Xiao, Shanghai Univ. (China): W. Luo, Shanghai Applied Radiation Institute (China); J. Wen, T. Wang, Shanghai Univ. (China)

878627 Broadband and high-efficiency metal-multilayer dielectric grating centered at $800 \mathbf{n m}$ based on non-quarter wave coatings as reflective mirror [8786-81]

S. Wang, W. Kong, M. Yun, W. Zhang, C. You, Z. Wang, G. Pan, M. Zhang, X. Li, X. Sun, Qingdao Univ. (China)

878629 Optical and thermal properties of a new Nd-doped phosphate laser glass [8786-84] W. Li, Shanghai Institute of Optics and Fine Mechanics (China) and Univ. of Chinese Academy of Sciences (China); D. He, S. Li, W. Chen, S. Chen, L. Hu, Shanghai Institute of Optics and Fine Mechanics (China)

8786 2B Defect structure and optical damage resistance of In:Er:LiTaO 3 crystals [8786-89] T. Sun, X. Zhang, Harbin Institute of Technology (China); L. Sun, Harbin Institute of Technology (China) and Yibin Univ. (China); R. Wang, Harbin Institute of Technology (China)

Author Index 


\section{Conference Committee}

Conference Chairs

Jianda Shao, Shanghai Institute of Optics and Fine Mechanics

(China)

Takahisa Jitsuno, Osaka University (Japan)

Wolfgang Rudolph, The University of New Mexico (United States)

\section{Conference Program Committee}

Norbert Kaiser, Fraunhofer-Institut für Angewandte Optik und Feinmechanik (Germany)

Efim A. Khazanov, Institute of Applied Physics (Russian Federation)

Zunqi Lin, Shanghai Institute of Optics and Fine Mechanics (China)

Yong Feng Lu, University of Nebraska-Lincoln (United States)

Alexander A. Manenkov, A. M. Prokhorov General Physics Institute (Russian Federation)

Richard Moncorgé, ENSICAEN (France)

Jean-Yves Natoli, Institut Fresnel (France)

Valdas Sirutkaitis, Vilnius University (Lithuania)

Christopher J. Stolz, Lawrence Livermore National Laboratory

(United States)

Koji Sugioka, RIKEN (Japan)

Takunori Taira, Institute for Molecular Science (Japan)

Mauro Tonelli, Università di Pisa (Italy)

Eric W. Van Stryland, CREOL, The College of Optics and Photonics, University of Central Florida (United States)

Zhouling Wu, ZC Optoelectronic Technologies, Ltd. (China)

Xiaomin Zhang, China Academy of Engineering Physics (China)

Jiping Zou, Ecole Polytechnique (France)

\section{Local Organizing Committee}

Ya Cheng, Shanghai Institute of Optics and Fine Mechanics (China)

Yaping Dai, Chinese Academy of Engineering Physics (China)

Hongbo He, Shanghai Institute of Optics and Fine Mechanics (China)

Guixue Huang, National High Technology Research and

Development Program 863 (China)

Yuxin Leng, Shanghai Institute of Optics and Fine Mechanics (China)

Liejia Qian, Shanghai Jiao Tong University (China)

Kui Yi, Shanghai Institute of Optics and Fine Mechanics (China)

Long Zhang, Shanghai Institute of Optics and Fine Mechanics (China) 
Overview of 2012 Laser Damage Symposium in Boulder

Jianda Shao, Shanghai Institute of Optics and Fine Mechanics (China)

1 High Power Laser Damage, UV through IR I

Takahisa Jitsuno, Osaka University (Japan)

Hongbo He, Shanghai Institute of Optics and Fine Mechanics (China)

2 Laser Ablation and Laser Machining I

Ya Cheng, Shanghai Institute of Optics and Fine Mechanics (China)

Zhouling Wu, ZC Optoelectronic Technologies, Ltd. (China)

3 Laser Ablation and Laser Machining II

Jean-Yves Natoli, Institut Fresnel (France)

Jiping Zou, Ecole Polytechnique (France)

4 Laser Ceramics

Takunori Taira, Institute for Molecular Science (Japan)

Efim A. Khazanov, Institute of Applied Physics (Russian Federation)

5 Defects, Contamination, Polishing, and Surface Damage

Jian Chen, ZC Optoelectronic Technologies, Ltd. (China)

Valdas Sirutkaitis, Vilnius University (Lithuania)

6 Nonlinear Laser Crystals I

Long Zhang, Shanghai Institute of Optics and Fine Mechanics (China)

Xinbin Cheng, Tongji University (China)

$7 \quad$ High Laser Damage Resistant Coatings

Valdas Sirutkaitis, Vilnius University (Lithuania)

Jean-Yves Natoli, Institut Fresnel (France)

8 Nonlinear Laser Crystals II

Mauro Tonelli, Università di Pisa (Italy)

Long Zhang, Shanghai Institute of Optics and Fine Mechanics (China)

9 Characterization Techniques and Measurement Protocols

Takahisa Jitsuno, Osaka University (Japan)

Wolfgang Rudolph, The University of New Mexico (United States)

10 Optical Glasses and Fibers

Jiping Zou, Ecole Polytechnique (France)

Mauro Tonelli, Università di Pisa (Italy) 
11 High Power Laser Damage, UV through IR II

Yi Liu, Laboratoire d'Optique Appliquée, ENSTA, Ecole Polytechnique (France)

Eric W. Van Stryland, CREOL, The College of Optics and Photonics, University of Central Florida (United States)

12 High Power Laser Damage, UV through IR III

Wolfgang Rudolph, The University of New Mexico (United States)

Yong Feng Lu, University of Nebraska-Lincoln (United States) 
Proc. of SPIE Vol. $8786878601-12$

Downloaded From: https://www.spiedigitallibrary.org/conference-proceedings-of-spie on 26 Apr 2023 Terms of Use: https://www.spiedigitallibrary.org/terms-of-use 